\title{
Whey protein concentration by ultrafiltration and study of functional properties
}

\author{
Sidiane Iltchenco ${ }^{1}$ Daiane Preci $^{1}$ Carla Bonifacino $^{2}$ Eugenia Franco Fraguas ${ }^{2}$ \\ Clarice Steffens $^{1^{*}}$ () Luis Alberto Panizzolo ${ }^{2}$ Rosicler Colet $^{1}$ Ilizandra Aparecida Fernandes ${ }^{1}$ \\ Cecilia Abirached $^{2}$ Eunice Valduga ${ }^{1}$ Juliana Steffens $^{1}$ ?
}

\author{
${ }^{1}$ Universidade Regional Integrada do Alto Uruguai e das Missões (URI), Erechim, RS, Brasil. E-mail: claristeffens@uricer.edu.br. \\ "Corresponding author.
}

${ }^{2}$ Universidad de la Republica, 11800, Montevideo, Uruguay.

\begin{abstract}
This paper aim to evaluate the ultrafiltration (UF) process for constituents recovery from whey. Sequences of factorial designs were performed by varying temperature $\left(5\right.$ to $\left.40^{\circ} \mathrm{C}\right)$ and pressure (1 to 3 bar), to maximize the proteins concentration using membrane of $100 \mathrm{kDa}$ in dead end system. Based on the best result new experiments were performed with membrane of 50kDa and $10 \mathrm{kDa}$. With the membrane of 50 the protein retention was about 3 times higher than the membrane of $100 \mathrm{kDa}$. The concentrated obtained by UF membrane of $10 \mathrm{kDa}, 10^{\circ} \mathrm{C}$ and $2 \mathrm{bar}$ in laboratory scale showed a mean protein retention of $80 \%$, greater protein solubility, emulsion stability and the identification of $\beta$-lactoglobulins $(18.3 \mathrm{kDa})$ and $\alpha$-lactalbumin fractions $(14.2 \mathrm{kDa})$. Therefore, the use of membrane of 100 and $50 \mathrm{kDa}$ are became a industrially recommendable alternatives to concentration of whey proteins, and/or as a previous step to the fractionation of whey constituents using membrane $\leq 10 \mathrm{kDa}$, aiming at future applications in different areas (food, pharmaceutical, chemical, etc.).
\end{abstract}

Key words: ultrafiltration, whey, dead-end; solubility and emulsion stability.

Concentração de proteínas de soro por ultrafiltração e estudo das propriedades funcionais

RESUMO: O objetivo do estudo foi avaliar o processo de Ultrafiltração (UF) na recuperação dos constituintes do soro de leite. Planejamentos fatoriais sequenciais foram realizados, variando a temperatura $\left(5\right.$ a $\left.40^{\circ} \mathrm{C}\right)$, a pressão (1 a 3 bar) e visando maximizar a concentração de proteínas usando membrana de $100 \mathrm{kDa}$ em sistema dead end. Baseados nos melhores resultados, foram realizados experimentos com de $50 \mathrm{kDa}$ e $10 \mathrm{kDa}$. Em relação a membrana de $50 \mathrm{kDa}$, a retenção de proteínas foi cerca de três vezes maior em relação a membrana de $100 \mathrm{kD}$. O concentrado obtido por membrana UF de $10 \mathrm{kDa}, 10^{\circ} \mathrm{C}$ e $2 \mathrm{bar}$, em escala laboratorial, mostrou uma retenção média de proteína de $80 \%$, maior solubilidade protéica, estabilidade da emulsão e a identificação das frações $\beta$-lactoglobulins (18.3kDa) e $\alpha$-lactalbumin (14.2kDa). Portanto, o uso de membranas de 100 e $50 \mathrm{kDa}$ são alternativas recomendáveis industrialmente à concentração de proteínas de soro de leite, e/ou como etapa anterior ao fracionamento de constituintes do soro usando membrana $\leq 10 \mathrm{kDa}$, visando aplicações futuras em difentes áreas (alimenticia, farmacêutica, química, etc).

Palavras-chave: Ultrafiltração, soro de leite, dead end, solubilidade, estabilidade de emulsão.

\section{INTRODUCTION}

The whey represent about 85 to $90 \%$ of the total volume of milk used for cheese production, and contains approximately $55 \%$ of milk nutrients, including proteins, lactose, soluble vitamins and minerals (BRANDELLI et al., 2015; PALATNIK et al., 2015). However, if on one hand the whey is viewed as a pollution agent, on the other side, it can be regarded as a value-added product, rich in nutrients, especially proteins with high biological quality, with nutritional and functional properties (emulsifying, foaming and gelling), may be incorporated into a wide range of foods (ARUNKUMAR \& ETZEL, 2015).
The protein concentration can improve the expression of their properties, allowing its use in different products in the trade. One alternative to recovery the whey constituents is to use membrane technology, where the ultrafiltration (UF) is the main process to fractionate whey constituents (BÁGUENA et al., 2015; WELSH et al., 2017).

In this context, the objective of the present study was to evaluate the UF process on recovery of milk whey constituents in laboratory scale, using a dead-end flow, with flat polysulfone amide membrane $(10,50$ and $100 \mathrm{kDa})$, evaluating permeate flows, physicochemical characteristics and functional property of the concentrates and permeates. 


\section{MATERIALS AND METHODS}

\section{Ultrafiltration process}

Bovine whey (in nature) was supplied by an industry of whey processing of the southern region of Brazil. The UF process (dead end) was conducted in laboratory scale. The system was composed of water bath with thermostat (Servilab, SE 100AG); nitrogen cylinder (analytical N2 5.0 - White Martins); UF membrane separation module (conventional flow, volume of 200mL); (d) Magnetic stirrer (ARE Heating Magnetic Stirrer- Scientific Velp). Three flat membranes were used in the work: one of $100 \mathrm{kDa}$, of polysulfone amide (GE-Osmonics (Sepa MW), one of 50kDa and one of $10 \mathrm{kDa}$ of polyethersulfone (Microdyn-Nadir $\mathrm{GmbH}$ ), with permeation area of $0.001134 \mathrm{~m}^{2}$. To evaluate the effects of temperature and pressure under the permeate and concentrate flow of the $100 \mathrm{kDa}$ membrane, a factorial design $2^{2}$ (design 1) was first carried out, varying the temperature $\left(20\right.$ to $\left.40^{\circ} \mathrm{C}\right)$ and the pressure (1 to 3 bar) for water and milk whey.

The levels of the variables were defined based on literature information (BALDASSO et al., 2016; BARUKCIC et al., 2014) and on preliminary tests. According to the results obtained in the Design 1 , a new factorial design $2^{2}$ (Design 2 ) was carried out, varying the temperature $\left(5\right.$ to $\left.15^{\circ} \mathrm{C}\right)$ and using the same pressure ( 1 to 3 bar). From the maximized condition obtained of the membrane of $100 \mathrm{kDa}$, were performed experiments with the membrane of $50 \mathrm{kDa}$ and $10 \mathrm{kDa}$. The dependent variables were the permeate flow of water and whey, total protein content, amount of solids, conductivity, acidity, $\mathrm{pH}$, lactose and total minerals in the concentrate and permeate.

The permeate flow $\left(\mathrm{J}_{\mathrm{m}}\right)$ were performed by the measurement of permeate collected in a graduated glass, calculated by the permeate volume (L) in relation to the permeation area $\left(\mathrm{m}^{2}\right)$ and the time (h). The water membrane resistance $(\mathrm{Rm})$ and milk whey resistance (Rt) were determined by Darcy's law for the membrane of $100 \mathrm{kDa}$. The whey viscosity at temperatures of $\left(15\right.$ and $\left.40^{\circ} \mathrm{C}\right)$ was determined using a Brookfield Mark rotational viscometer (PROGRAMMABLE DV-III + Rheometer). The water viscosity data at temperatures of 15 and $40^{\circ} \mathrm{C}$ were taken from SHAMES (1995).

The rejection coefficient was calculated for protein, total solids, lactose and minerals by the relation between the concentration in the feed and its concentration in the permeate.

The rejection coefficient $(\mathrm{R})$ was calculated according to equation 1 (PABBY et al., 2015).

$$
R=\left(\frac{c_{r}-c_{p}}{c_{r}}\right) \times 100=\left(1-\frac{c_{p}}{c_{r}}\right) \times 100
$$

Where: $c_{r}$ represents the concentration of a solute in the retentate and $c_{p}$ is the concentration of the same solute in the permeate, and the rejection is presented in $\%$.

\section{Physico-chemical characterization}

The in nature whey and the fractions of concentrates and permeates obtained from the UF processes were analyzed in relation to total protein Kjeldahl method (AOAC, 2005); separation of protein fractions and identification of molecular weight by electrophoresis according to LAEMMLI (1970); total solids by the gravimetric method in a recirculation oven (Fanem - model 320 - SE) at $105^{\circ} \mathrm{C}$ until constant weight (BRASIL, 2005); electrical conductivity using a conductivity meter (RS 232-METER 8306); total acidity was expressed in Dornic (AOAC, 2005); $\mathrm{pH}$ by potentiometric method (AOAC, 2005); lactose by the DNS method (3,5-dinitro salicylate) according to methodology described by MILLER (1959); total minerals was determined according to the methodology described by BRASIL (2005).

The protein soluble was measured of the concentrate obtained by UF (50 and $10 \mathrm{kDa})$ lyophilized, where the sample was determined by dispersing in $10 \mathrm{mM}$ sodium phosphate buffer $(\mathrm{pH}$ 7.0) and stirring for $30 \mathrm{~min}$ at room temperature to prepare a $0.1 \% \mathrm{w} / \mathrm{v}$ solution. The dispersions were then centrifuged at $10,000 \times \mathrm{g}$ for $10 \mathrm{~min}$ at $4^{\circ} \mathrm{C}$ and the protein content of the supernatant was determined by the Lowry method (LOWRY et al., 1951).

\section{Emulsion preparation}

The emulsions were prepared with and oil: water $(\mathrm{o} / \mathrm{w})$ ratio of $25: 75 \mathrm{v} / \mathrm{v}$. The aqueous phase was a solution of soluble proteins of $1 \mathrm{mg} / \mathrm{mL}$ concentration in phosphate buffer $0.01 \mathrm{M} \mathrm{pH} 7.0$. The oil used was commercial sunflower oil. The emulsions were done by mixing the aqueous and oil phases with an Ultraturrax homogenizer (IKA-Labortechnik) at 20,000rpm during $1 \mathrm{~min}$.

\section{Creaming stability}

Immediately after homogenization creaming stability of the o/w emulsions were optically characterized using a vertical scan analyzer (Turbiscan Classic MA2000, Formulation. Toulouse, France). Curves of backscattering (\% BS) and transmission percentages as a function of time and tube length were obtained.

The studies of creaming and destabilization of the emulsions were made by measuring retrodispersion 
once a minute for $60 \mathrm{~min}$. The kinetics of destabilization was determined at a tube length of 10-20mm according model developed by PANIZZOLO et al. (2014).

The measure of $\mathrm{BS}$ is linked to the concentration and average size of the emulsion droplets as a function of the height measuring device (ABISMAIIL et al., 2000). From the profiles obtained the mean values for $\%$ BS were calculated in the $50-53 \mathrm{~mm}$ zone (\% BS-50-53), corresponding to the cream part of the tube. To measure the global stability of the emulsions after $24 \mathrm{~h}$ of storage, the destabilization percentage ( $\%$ D) was defined by PALAZOLO et al. (2005).

\section{Statistical analysis}

The results obtained from the experimental design where used to evaluated the differences between means variance analysis (ANOVA) follow by Tukey's test and/or t student using Statistic software, version 5.0 , at a significance level of $95 \%$ of confidence.

\section{RESULTS AND DISCUSSION}

\section{Effects of pressure and temperature on the membrane of $100 \mathrm{kDa}$}

Table 1 shows the matrix of the factorial design $2^{2}$ (real and coded values) - Design 1 , and values of mean permeate flow $\left(\mathrm{L} \mathrm{m}^{-2} \mathrm{~h}^{-1}\right)$ for water and whey, obtained from the UF process with membrane of $100 \mathrm{kDa}$. For water high flows (Table 1) were verified in the tests 5, 6 and 7 (Design 1) which was operated at $30^{\circ} \mathrm{C}$ and 2 bar. While for the whey the highest flow was $24.82 \mathrm{~L} / \mathrm{m}^{2} \mathrm{~h}$ at $40^{\circ} \mathrm{C}$ and 3 bar (test 4 - Design 1) and the lowest was $14.17 \mathrm{Lm}^{-2} \mathrm{~h}^{-1}$ at $5^{\circ} \mathrm{C}$ and 1 bar (test 1 - Design 2).

Equations 2 and 3 shows a first order coded model for whey flow as a function of temperature and pressure, for the designs 1 and 2, within the ranges studied. The models were validated by variance analysis (ANOVA). The correlation coefficients were 0.95 and 0.91 , and the results were significative $(\mathrm{p}<0.05$ ), allowing the construction of the contour curves (Figure 1)

$\mathrm{FMS}=21.25+1.05 \mathrm{X}_{1}+3.65 \mathrm{X}_{2}$ $\mathrm{FMS}=17.02+0.64 \mathrm{X}_{1}+1.64 \mathrm{X}_{2}$

Where FMS is the whey flow $\left(\mathrm{L} / \mathrm{m}^{2} \mathrm{~h}\right), \mathrm{X}_{1}$ is the temperature $\left({ }^{\circ} \mathrm{C}\right)$ and $\mathrm{X}_{2}$ is the pressure (bar).

The larger mean whey permeates flows were obtained at high pressures and temperatures, being recommended ranges of pressures greater than 2 bar and temperatures above $10^{\circ} \mathrm{C}$. These temperatures seem to be more suitable, since no acidification was verified in the concentrates (Table 2). Low temperatures may have additional benefits in the filtration which reducing on the denaturation of whey proteins, reducing on the membrane fouling caused by calcium phosphates and reduce the growth of thermophilic bacteria. However, lower temperatures reduce diffusivity, and hence mass

Table 1 - Matrix of the factorial design $2^{2}$ (real and coded values) - Designs 1 and 2 and values of permeate flow (Lm ${ }^{-2} \mathrm{~h}^{-1}$ ) for water and whey using membrane of $100 \mathrm{kDa}$.

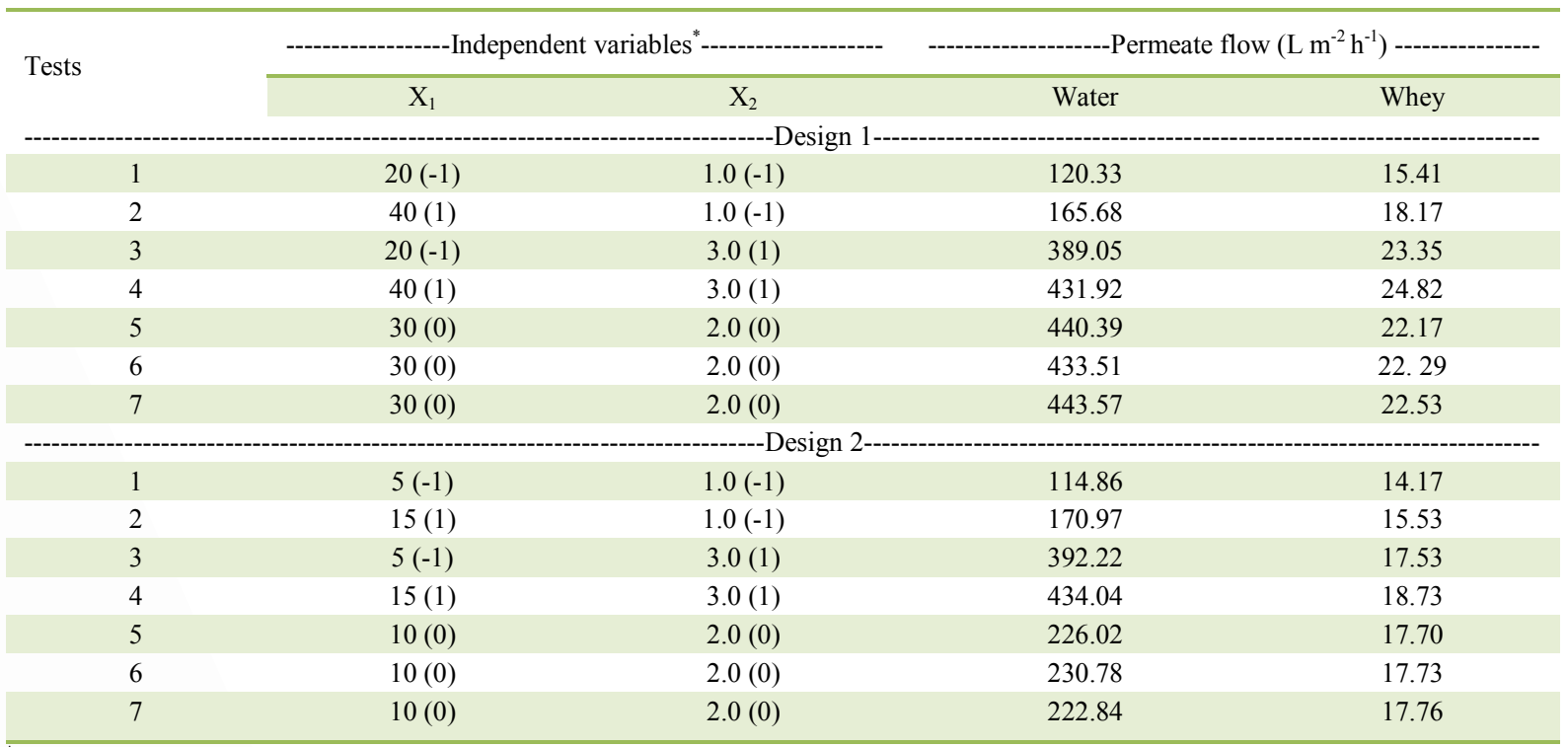

${ }^{*} \mathrm{X}_{1}=$ Temperature $\left({ }^{\circ} \mathrm{C}\right) ; \mathrm{X}_{2}=$ Pressure (bar). Fixed dependent variables: feed volume $(200 \mathrm{~mL})$ 

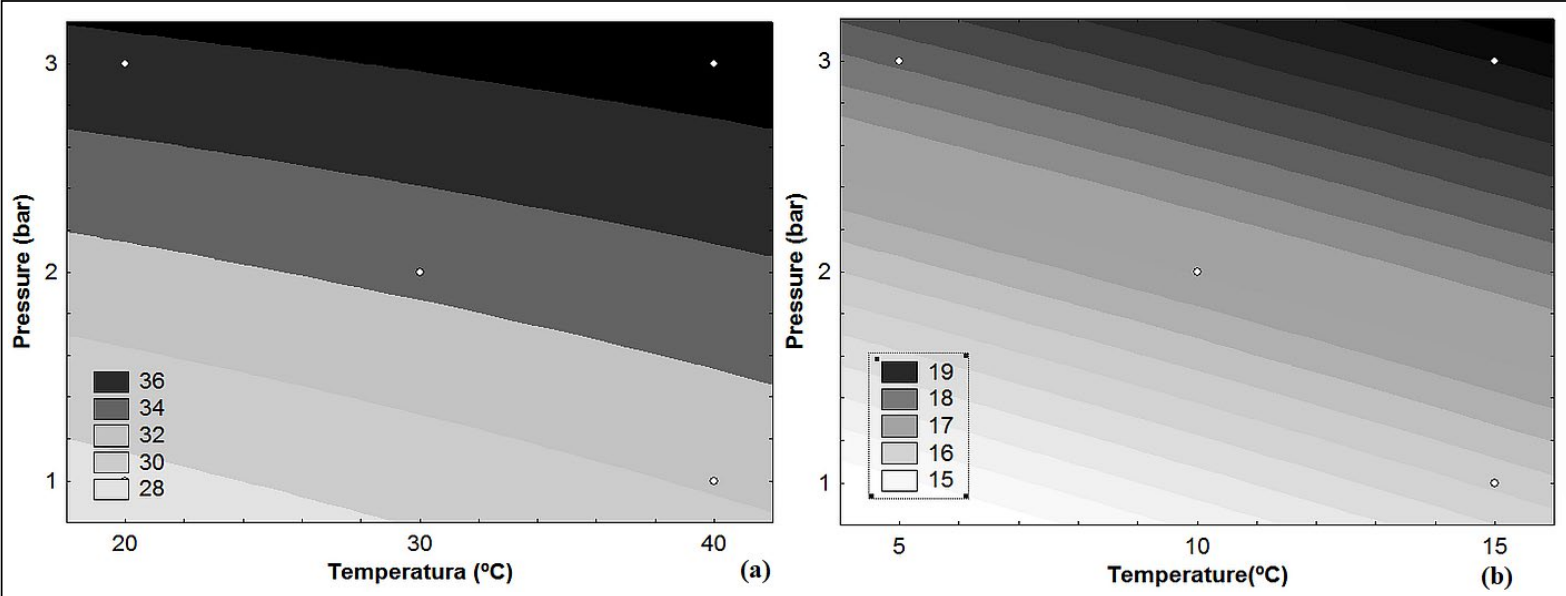

Figure 1 - Contour curves for whey flow $\left(\mathrm{L} / \mathrm{m}^{2} \mathrm{~h}\right)$, obtained in the Design 1 (a) and 2 (b), respectively.

transfer coefficient, resulting in flow rates lower than UF performed at high temperatures, regardless of the membrane pore size.

Although the contour curves (Figure 1) indicate largest permeate flows at 3 bar, caution is required in setting the operating pressure. Whey in this system with high pressures intensified the polarization phenomena by concentration and fouling of the membrane, resulting in permeate flow similar to those obtained at 2 bar. So the pressure of 2 bar appears to be more suitable for whey UF in this system.

The permeate flow for water (Figure 2A-C) showed almost stationary profile over the time for all tests, and this behavior is already expected since the fluid used (deionized water) is free of contaminants (suspended and dissolved material). In the whey flow (Figure 2B-D) for all tests we can observed that there was a decrease in the permeate flow over the operating time, this fall is mainly due to polarization phenomena of concentration and fouling. It occurred since the components of the whey, mainly the proteins, are retained and accumulate on the membrane surface forming a barrier. Another factor that can decrease the flow is the type of flow (conventional) since has a greater concentration of particles next to the membrane with the time, causing a greater fall in the permeate flow due to the increase of the filtration resistance due to the increase of cake resistance.

The permeate flow of whey (Figure 2B-D), test 1 and 2 at 1 bar presented lower flow than the other test, and the tests 3 and 4, and 56 and 7 which operated at 3 and 2 bar respectively not showed differences.

Table 2 - Matrix of the factorial design $2^{2}$ (real and coded values) - Design 1 and response in terms of pH and acidity $\left({ }^{\circ} \mathrm{D}\right)$ for the concentrates and permeates obtained after UF.

\begin{tabular}{|c|c|c|c|c|c|c|}
\hline \multirow{2}{*}{ Tests } & \multicolumn{2}{|c|}{---Independent variables"---- } & \multicolumn{2}{|c|}{-------------------------pH } & \multicolumn{2}{|c|}{-----------------Acidity ${ }^{*}\left({ }^{\circ} \mathrm{D}\right)$------------- } \\
\hline & $X_{1}$ & $\mathrm{X}_{2}$ & Concentrate & Permeate & Concentrate & Permeate \\
\hline 1 & $20(-1)$ & $1.0(-1)$ & $5.00^{\mathrm{b}}( \pm 0.01)$ & $5.12^{\mathrm{a}}( \pm 0.03)$ & $27.10^{\mathrm{a}}( \pm 0.85)$ & $22.83^{\mathrm{b}}( \pm 0.29)$ \\
\hline 2 & $40(1)$ & $1.0(-1)$ & $4.37^{\mathrm{b}}( \pm 0.03)$ & $4.49^{\mathrm{a}}( \pm 0.01)$ & $31.73^{\mathrm{a}}( \pm 0.64)$ & $28.50^{\mathrm{b}}( \pm 0.50)$ \\
\hline 3 & $20(-1)$ & $3.0(1)$ & $5.14^{\mathrm{b}}( \pm 0.03)$ & $5.20^{\mathrm{a}}( \pm 0.03)$ & $26.30^{\mathrm{a}}( \pm 0.20)$ & $23.03^{\mathrm{b}}( \pm 0.06)$ \\
\hline 4 & $40(1)$ & $3.0(1)$ & $4.40^{\mathrm{b}}( \pm 0.01)$ & $4.51^{\mathrm{a}}( \pm 0.01)$ & $30.33^{\mathrm{a}}( \pm 0.29)$ & $27.67^{\mathrm{b}}( \pm 0.58)$ \\
\hline 5 & $30(0)$ & $2.0(0)$ & $4.66^{\mathrm{b}}( \pm 0.01)$ & $5.01^{\mathrm{a}}( \pm 0.03)$ & $26.43^{\mathrm{a}}( \pm 0.51)$ & $23.17^{\mathrm{b}}( \pm 0.29)$ \\
\hline 6 & $30(0)$ & $2.0(0)$ & $4.65^{\mathrm{b}}( \pm 0.01)$ & $4.98^{\mathrm{a}}( \pm 0.01)$ & $26.50^{\mathrm{a}}( \pm 0.50)$ & $23.50^{\mathrm{b}}( \pm 0.50)$ \\
\hline 7 & $30(0)$ & $2.0(0)$ & $4.64^{\mathrm{b}}( \pm 0.01)$ & $5.0^{\mathrm{a}}( \pm 0.02)$ & $26.33^{\mathrm{a}}( \pm 0.58)$ & $23.33^{\mathrm{b}}( \pm 0.58)$ \\
\hline
\end{tabular}

${ }^{*} \mathrm{X}_{1}=$ Temperature $\left({ }^{\circ} \mathrm{C}\right) ; \mathrm{X}_{2}=$ Pressure (bar); ${ }^{* *}$ mean ( \pm standard deviations) followed by same letters on lines represents no significant difference at $5 \%$ level (t student test). Fixed independent variables: feed volume $(200 \mathrm{~mL})$, UF time of $90 \mathrm{~min}$.

Ciência Rural, v.48, n.5, 2018. 


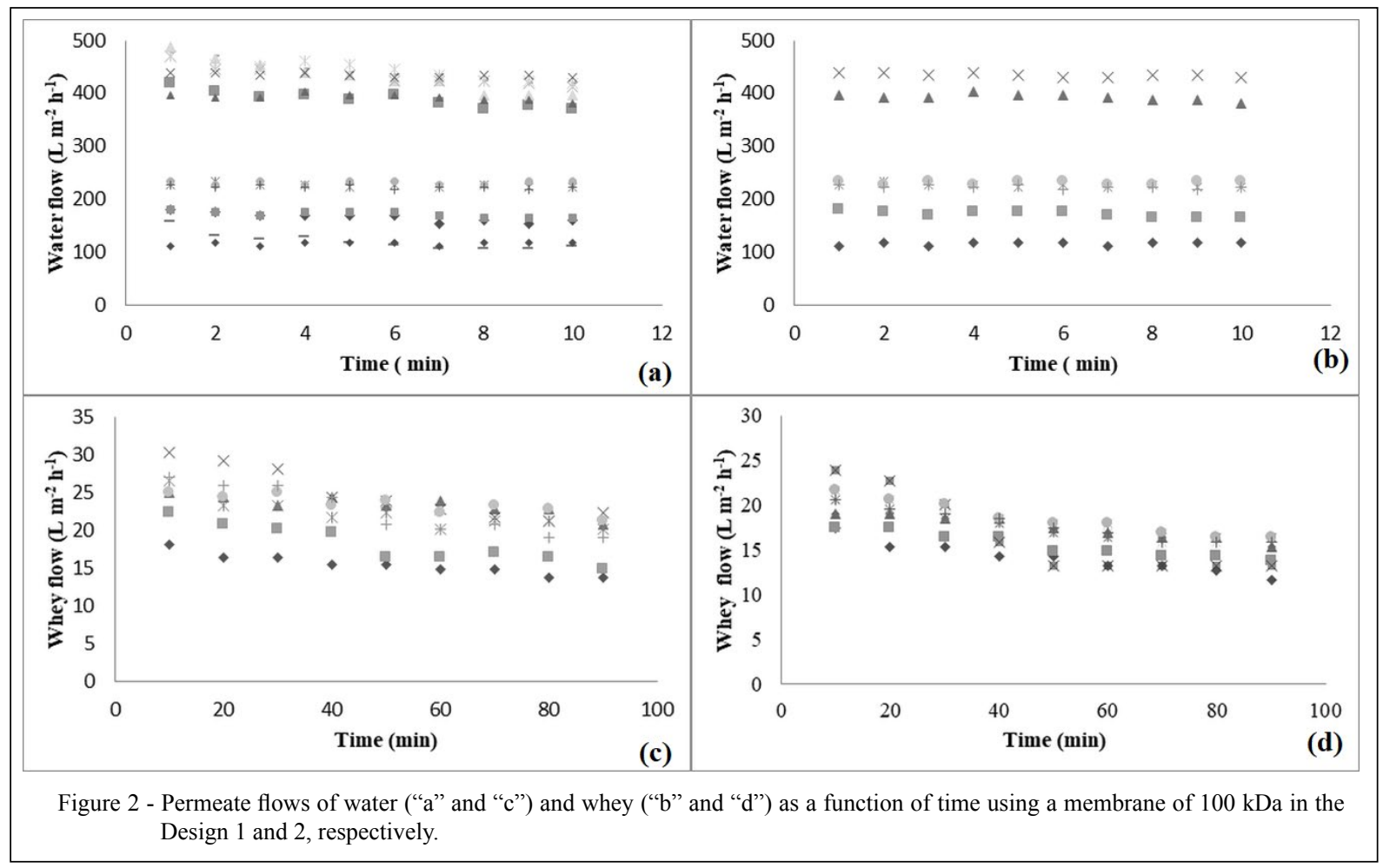

Possibly for this process at 2 bar is the limit flow, which is reached when the pressure increase in the system no influences in the flow increase, where the flow remains practically constant independent of the increase in pressure. In this case the protein molecules are deposited on the membrane surface, forming a gel layer, causing the phenomena of fouling and polarization by concentration, and this layer causes an additional resistance to permeate flow.

At high temperatures the whey viscosity is reduced, increasing the fluid speed directed to the membrane, in this way increasing its initial permeation and the drag of solutes towards the membrane, accelerating the concentration polarization.

The UF membrane resistance using whey at $40^{\circ} \mathrm{C}$ (viscosity of $1.79 \times 10^{-3} \mathrm{~kg} \mathrm{~m}^{-1} \mathrm{~s}^{-1}$ ) was $2.43 \times 10^{7}$ $\mathrm{m}^{-1}$, around 6.34 times higher than obtained for water. While, at $15^{\circ} \mathrm{C}$ (viscosity of $2.07 \times 10^{-3} \mathrm{~kg} \mathrm{~m}^{-1} \mathrm{~s}^{-1}$ ) the resistance of the whey was $2.77 \times 10^{7} \mathrm{~m}^{-1}$, being 12.70 times higher than that found for water. The highest resistance observed for whey in relation to water at both temperatures is given as a function of the solids present in the solution that difficult the membrane cross, besides the whey viscosity is higher than the water, making it difficult to cross the membrane.

The in nature whey had an average composition: $5.6 \%$ total solids, $4.66 \%$ lactose, $0.91 \%$ protein, $0.6 \%$ total minerals, $\mathrm{pH}$ of 6.49 and acidity of $12.20^{\circ} \mathrm{D}$. In relation to $\mathrm{pH}$ and acidity the whey can be classified as sweet whey (MACEDO et al., 2015).

Table 2 shows the matrix of factorial design $2^{2}$ (real and coded values) - Design 1 the response in terms of $\mathrm{pH}$ and acidity $\left({ }^{\circ} \mathrm{D}\right)$ for the concentrate and permeate obtained after the UF using flat membrane of $100 \mathrm{KDa}$. Both permeate and concentrate shows an increase in the acidity compared with the in nature whey $\left(12.20^{\circ} \mathrm{D}\right)$, possibly due of the bacteria action during the remained of the whey in the UF system. The acid values for the concentrates were higher $(p<0.05)$ than those found for permeate in all the tests. The highest acidity levels $\left(31.73\right.$ and $\left.30.33^{\circ} \mathrm{D}\right)$ were observed in concentrates at $40^{\circ} \mathrm{C}$ (tests 2 and 4).

The increase in acidity levels observed in Design 1 (Table 2) occurred due to lactose degradation (data not shown) and lactic acid production due to the action of lactic acid bacteria present in the whey, because the temperatures $20-40^{\circ} \mathrm{C}$ are considered optimal for its development. This could be seen by the Pareto chart (Figure 3A) were the acidity was positively influenced $(\mathrm{P}<0.05)$ by the temperature. Similarly, in both fractions (permeated and concentrated) a decrease in $\mathrm{pH}$ occurred in relation to in nature milk (mean $\mathrm{pH}$ 6.49). The lower $\mathrm{pH}$ values for permeates (4.49) and the concentrates $(4.37)$ were obtained at $40^{\circ} \mathrm{C}$.

Based on concentrates results a new factorial design (Design 2) was conducted for UF with a flat 


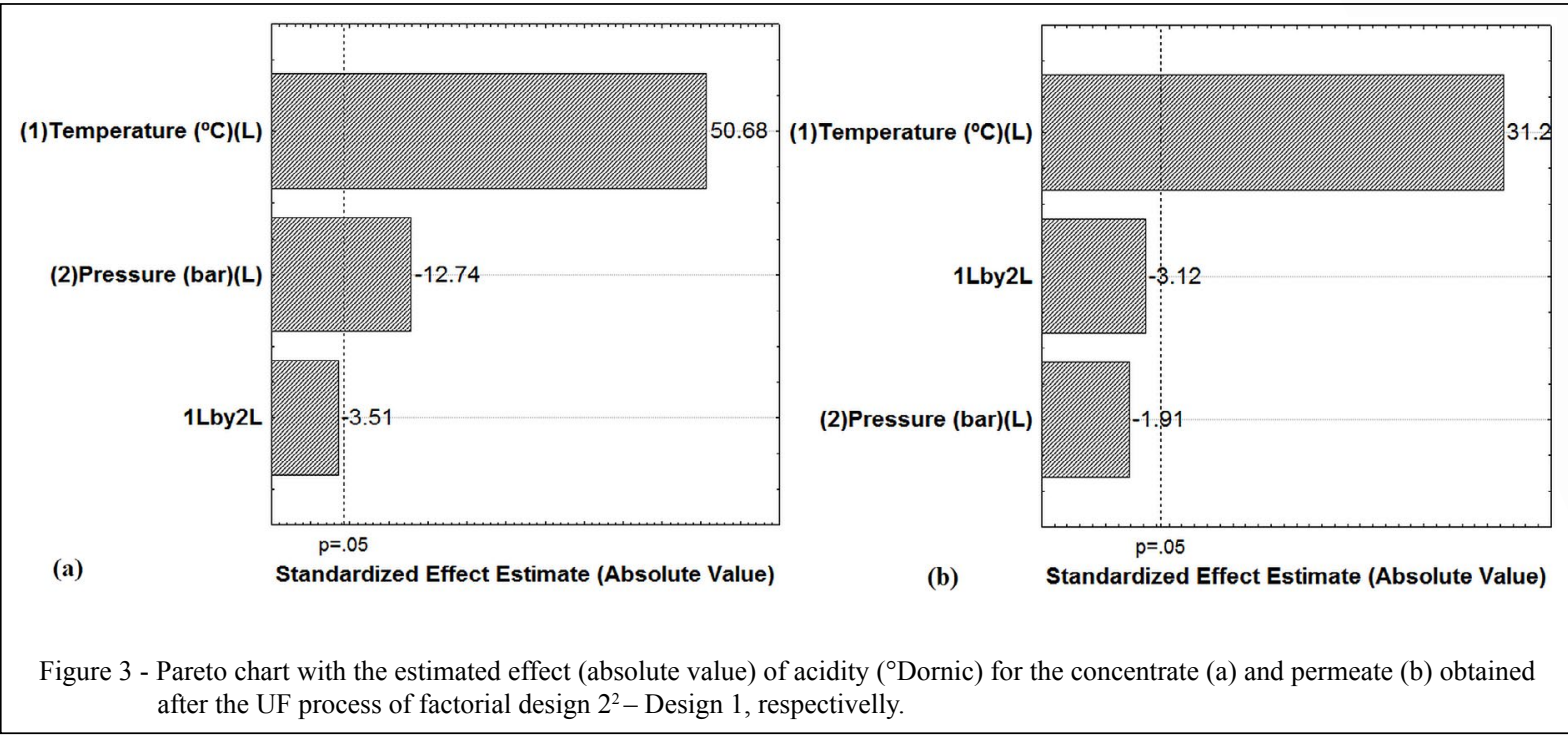

membrane of $100 \mathrm{kDa}$, where the temperature levels were 5,10 and $15^{\circ} \mathrm{C}$ and the pressures were maintained at the same levels of the Design 1 (Table 3) due to system limitation. No significant difference $(\mathrm{P}>0.05)$ was observed between the acidity and $\mathrm{pH}$ of permeate and concentrate in the experiments, and the acidity values were similar to those obtained in the in nature whey $\left(12.20^{\circ} \mathrm{D}\right)$. For the permeated fractions the $\mathrm{pH}$ presented a variation between 6.44 and 6.50 , while the concentrated fractions presented slightly lower values $(\mathrm{P}<0.05)$ in all the tests ranging from 6.33 to 6.42 .

Equations 4, 5 and 6 shows the first order coded models for acidity, $\mathrm{pH}$ and solids rejection, respectively, of the concentrates as a function of temperature (significate variables $\mathrm{P}<0.05$ ). The model was validated by variance analysis (ANOVA), with correlation coefficient of $0.95,0.92$ and 0.99 , and the results were significate $(\mathrm{P}<0.05)$, allowing

Table 3 - Tests the factorial design $2^{2}$ (real and coded values) - Design 2 and response in terms of pH, acidity ( ${ }^{\circ} \mathrm{D}$ ), conductivity and rejection coefficient (protein, solids, lactose and minerals) for the concentrates and permeates obtained after UF.

\begin{tabular}{|c|c|c|c|c|c|c|c|c|c|c|}
\hline \multirow[t]{2}{*}{ Test } & \multicolumn{2}{|c|}{---------------pH } & \multicolumn{2}{|c|}{-------Acidity ${ }^{*}\left({ }^{\circ} \mathrm{D}\right)-------$} & \multicolumn{2}{|c|}{-Conductivity $\left(\mathrm{mS} \mathrm{cm}^{-1}\right)^{*}--$} & \multicolumn{4}{|c|}{----Rejection Coefficient $(\%)^{*}----$} \\
\hline & Concentrate & Permeate & Concentrate & Permeate & Concentrate & Permeate & P. & S. & L. & M. \\
\hline 1 & $\begin{array}{c}6.41^{\mathrm{b}} \\
( \pm 0.01)\end{array}$ & $\begin{array}{c}6.50^{\mathrm{a}} \\
( \pm 0.02)\end{array}$ & $\begin{array}{c}12.33^{\mathrm{a}} \\
( \pm 0.58)\end{array}$ & $\begin{array}{c}12.17^{\mathrm{a}} \\
( \pm 0.76)\end{array}$ & $\begin{array}{c}5.12^{\mathrm{b}} \\
( \pm 0.02)\end{array}$ & $\begin{array}{c}5.22^{\mathrm{a}} \\
( \pm 0.03)\end{array}$ & 70.33 & 21.79 & 4.72 & 20.00 \\
\hline 2 & $\begin{array}{c}6.33^{\mathrm{b}} \\
( \pm 0.01)\end{array}$ & $\begin{array}{c}6.45^{\mathrm{a}} \\
( \pm 0.03)\end{array}$ & $\begin{array}{c}13.33^{\mathrm{a}} \\
( \pm 1.15)\end{array}$ & $\begin{array}{c}12.67^{\mathrm{a}} \\
( \pm 0.50)\end{array}$ & $\begin{array}{c}5.14^{\mathrm{b}} \\
( \pm 0.03)\end{array}$ & $\begin{array}{c}5.25^{\mathrm{a}} \\
( \pm 0.05)\end{array}$ & 64.84 & 19.64 & 5.15 & 18.33 \\
\hline 3 & $\begin{array}{c}6.42^{\mathrm{b}} \\
( \pm 0.03)\end{array}$ & $\begin{array}{c}6.50^{\mathrm{a}} \\
( \pm 0.04)\end{array}$ & $\begin{array}{c}12.33^{\mathrm{a}} \\
( \pm 0.29)\end{array}$ & $\begin{array}{c}12.33^{\mathrm{a}} \\
( \pm 0.58)\end{array}$ & $\begin{array}{c}5.13^{\mathrm{b}} \\
( \pm 0.05)\end{array}$ & $\begin{array}{c}5.23^{\mathrm{a}} \\
( \pm 0.03)\end{array}$ & 67.03 & 18.04 & 3.43 & 21.67 \\
\hline 4 & $\begin{array}{c}6.36^{\mathrm{b}} \\
( \pm 0.03)\end{array}$ & $\begin{array}{c}6.47^{\mathrm{a}} \\
( \pm 0.01)\end{array}$ & $\begin{array}{c}13.67^{\mathrm{a}} \\
( \pm 0.58)\end{array}$ & $\begin{array}{c}13.17^{\mathrm{a}} \\
( \pm 0.29)\end{array}$ & $\begin{array}{c}5.15^{\mathrm{b}} \\
( \pm 0.04)\end{array}$ & $\begin{array}{c}5.24^{\mathrm{a}} \\
( \pm 0.04)\end{array}$ & 64.84 & 17.50 & 3.86 & 20.00 \\
\hline 5 & $\begin{array}{c}6.38^{\mathrm{b}} \\
( \pm 0.01)\end{array}$ & $\begin{array}{c}6.46^{\mathrm{a}} \\
( \pm 0.03)\end{array}$ & $\begin{array}{c}13.00^{\mathrm{a}} \\
( \pm 1.00)\end{array}$ & $\begin{array}{c}12.33^{\mathrm{a}} \\
( \pm 0.58)\end{array}$ & $\begin{array}{c}5.14^{\mathrm{b}} \\
( \pm 0.04)\end{array}$ & $\begin{array}{c}5.26^{\mathrm{a}} \\
( \pm 0.03)\end{array}$ & 72.53 & 18.93 & 4.72 & 21.67 \\
\hline 6 & $\begin{array}{c}6.39^{\mathrm{b}} \\
( \pm 0.02)\end{array}$ & $\begin{array}{c}6.46^{\mathrm{a}} \\
( \pm 0.02)\end{array}$ & $\begin{array}{c}12.67^{\mathrm{a}} \\
( \pm 0.51)\end{array}$ & $\begin{array}{c}12.33^{\mathrm{a}} \\
( \pm 0.58)\end{array}$ & $\begin{array}{c}5.15^{\mathrm{b}} \\
( \pm 0.03)\end{array}$ & $\begin{array}{c}5.25^{\mathrm{a}} \\
( \pm 0.05)\end{array}$ & 70.33 & 18.75 & 4.51 & 23.33 \\
\hline 7 & $\begin{array}{c}6.36^{\mathrm{b}} \\
( \pm 0.02)\end{array}$ & $\begin{array}{c}6.44^{\mathrm{a}} \\
( \pm 0.03)\end{array}$ & $\begin{array}{c}12.67^{\mathrm{a}} \\
( \pm 0.58)\end{array}$ & $\begin{array}{c}12.00^{\mathrm{a}} \\
( \pm 1.00)\end{array}$ & $\begin{array}{c}5.13^{\mathrm{b}} \\
( \pm 0.04)\end{array}$ & $\begin{array}{c}5.24^{\mathrm{a}} \\
( \pm 0.04)\end{array}$ & 71.43 & 18.75 & 4.08 & 23.33 \\
\hline
\end{tabular}

${ }^{*}$ mean ( \pm standard deviations) followed by same letters on lines represents no significant difference at $5 \%$ level ( $\mathrm{t}$ student test). Fixed independent variables: feed volume $(200 \mathrm{~mL})$, UF time of $90 \mathrm{~min} . \mathrm{P}=$ protein; $\mathrm{S}=$ solids; lactose; $\mathrm{M}=$ minerals. 
the construction of the contour curves (Figure 4).

$\mathrm{ACID}_{\mathrm{C}}=12.856+0.598 \mathrm{X}_{1}$

$\mathrm{pH}_{\mathrm{C}}=6.377-0.368 \mathrm{X}_{1}$

$\mathrm{R}_{\mathrm{st}}=6.09-0.67 \mathrm{X}_{1}-1.47 \mathrm{X}_{2}+0.4 \mathrm{X}_{1} \mathrm{X}_{2}$

Where $\mathrm{ACID}_{\mathrm{c}}$ is the concentrate acidity $\left({ }^{\circ} \mathrm{D}\right), \mathrm{pH}_{\mathrm{c}}$ is the concentrate $\mathrm{pH}, \mathrm{R}_{\mathrm{st}}$ is the rejection coefficient, $\mathrm{X}_{1}$ is the temperature $\left({ }^{\circ} \mathrm{C}\right)$ and $\mathrm{X}_{2}$ is the pressure (bar).

Lower acid (Figure 4A) values of the concentrates are found below of $10^{\circ} \mathrm{C}$ regardless of the pressure used. The lowest solids retentions (higher rejections) (Figure 4B) were obtained at pressures and temperatures on the ranges of $1-2$ bar and $5-10^{\circ} \mathrm{C}$. The results can be justified in this conditions decrease the passage of solids to the permeate stream causing more retention.

Conductivity of 5.13 and $5.24 \mathrm{mS} . \mathrm{cm}^{-1}$ were observed (Table 3 ) in the concentrates and permeates, respectively, and none of the variables studied had a significant effect $(\mathrm{P}>0.05)$ on the conductivity (Pareto chart not present). Thus, high conductivity observed in permeate is due to the amount of inorganic substances (salts), since they are completely permeable.

The high rejection of protein was $72.53 \%$ (Test 5 at $10^{\circ} \mathrm{C}$ and 2 bar). By the Pareto chart (Figure not show) was not observed significant influence $(\mathrm{P}>0.05)$ of the variables, within the studied range. In the literature, there are few studies that used of flat membranes of $100 \mathrm{kDa}$ in the whey processing. Although the used membrane of $100 \mathrm{kDa}$ presents high MWCO, the results indicate that it may be a good alternative for pre-concentration of proteins $(1.35 \mathrm{~g} / 100 \mathrm{~mL})$ at 3 bar and $15^{\circ} \mathrm{C}$ (Test 4$)$.

For the retention of lactose, it was less than 5.5\% (Table 3), however, not present significant effects $(\mathrm{P}>0.05)$ to temperature and pressure (Pareto chart not show). The obtained values indicate a partial retention of lactose which difficulty the proteins purification. Theoretically, a membrane of $100 \mathrm{kDa}$ could not retain lactose, since this is a neutral solute and has less molecular mass than the cut-off molar mass of the membrane. However, fouling and the formation of a gel layer on the membrane surface could be factors that change the selectivity, resulting in rejection of some components with lower molar mass to cut off of the membrane.

A rejection of $22 \%$ of total minerals was obtained, but no present significative influence $(\mathrm{P}>0.05)$ on pressure and temperature. The apparent rejection observed should be the layer formation on the membrane surface preventing the cross of these solutes. Based on the results obtained for the permeate flow of whey to the membrane of $100 \mathrm{kDa}$, in which a flow limit for the process was observed at a pressure of 2 bar and temperatures on the range of 5 to $10^{\circ} \mathrm{C}$ are more recommended were occur greater rejection of solids and protein. In this sense, were development new experiments using membrane of 50 and $10 \mathrm{kDa}, 10^{\circ} \mathrm{C}$ and 2 bar.

\section{Effects of pressure and temperature on the membrane of 50 and $10 \mathrm{kDa}$}

For the membrane of 50 and $10^{\circ} \mathrm{kDa}$, the conditions of $10^{\circ} \mathrm{C}$ and 2 bar were chosen, based on the results obtained for the permeate flow of whey
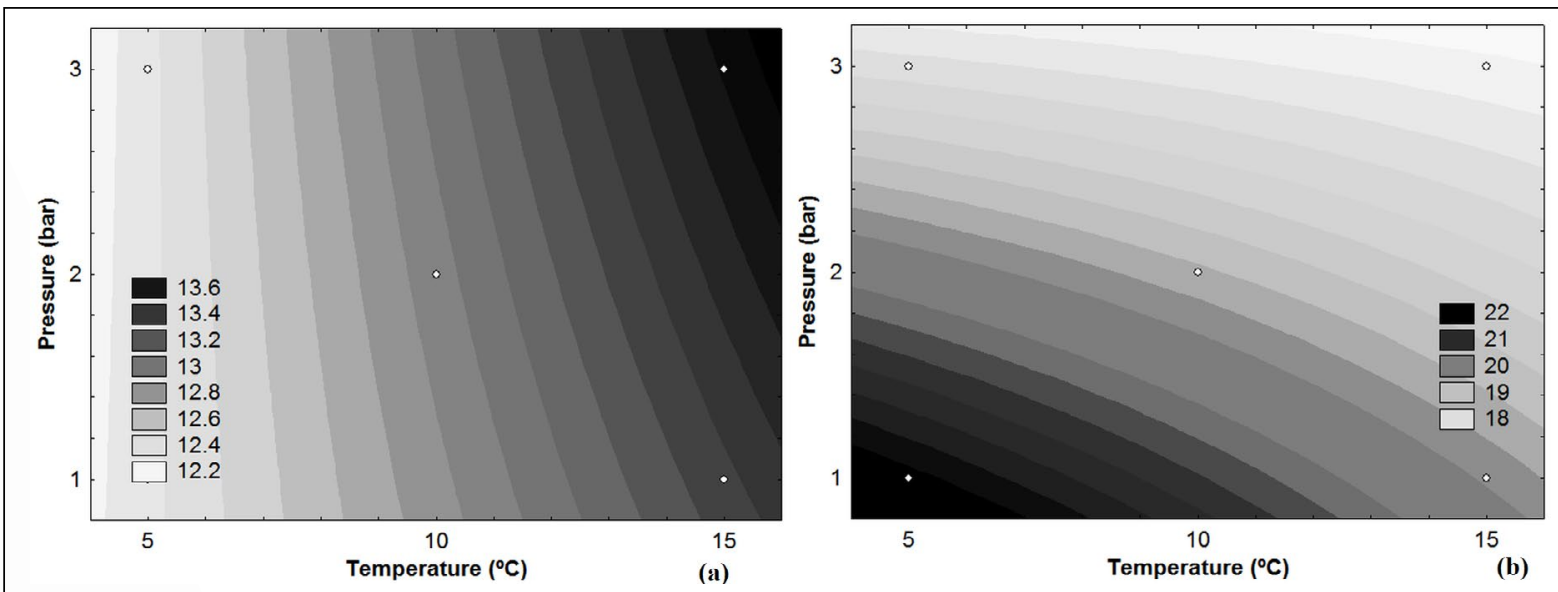

Figure 4 - Contour curves for acidity (a) and rejection coefficient for total solids (b) of concentrate whey obtained in UF process with a flat membrane of $100 \mathrm{kDa}$ in the Design 2. 
membrane of $100 \mathrm{kDa}$, which presented a limit flow (when an increase pressure no leads to a significant increase in flow). Also, $10^{\circ} \mathrm{C}$ seems to be more indicated, since the temperature of $15^{\circ} \mathrm{C}$ shows a tendency for small acidifications in the whey and temperatures of $5^{\circ} \mathrm{C}$ resulted in lower flow rates.

Was observed in the first $20 \mathrm{~min}$ the permeate flow $\left(10^{\circ} \mathrm{C}\right.$ and 2 bar) a rapid and very sharp drop due mainly to the concentration polarization that occurs by increasing the solids concentration near the membrane surface. Over time (20 to $60 \mathrm{~min}$ ), a decrease flow occurred in smaller a dimension, which is caused by the particles deposition and retention under or inside the membrane pores, a phenomenon known as fouling. After $60 \mathrm{~min}$ a slower decrease is observed, which may be due to a greater deposition of particles or consolidation of the fouling layer (Figure not shown). After 90min the permeate flow had a reduction of $50.80 \%$, from $11.12 \mathrm{~L}$ $\mathrm{m}^{-2} \mathrm{~h}^{-1}$ at the beginning of the process to $5.47 \mathrm{~L} \mathrm{~m}^{-2} \mathrm{~h}^{-1}$, again evidencing the phenomena of polarization by concentration and Fouling.

In relation to the mean flow rate, the membrane of $50 \mathrm{kDa}$ presented a flow of $7.19 \mathrm{Lm}^{-2} \mathrm{~h}^{-1}$, which was $59.42 \%$ lower than that obtained for the membrane of $100 \mathrm{kDa}$ under the same conditions $\left(10^{\circ} \mathrm{C}\right.$ and $\left.2 \mathrm{bar}\right)$. This reduction was expected since the membrane has a much lower pore size, in addition the membranes present differences in their composition which may alter the mode of interaction of the whey with the membrane material.

MACEDO et al. (2015), emphasize that in UF of whey the proteins (mainly $\beta$-lactoglobulin ( $\beta$ Lg) and $\alpha$-lactalbumin ( $\alpha$-La) and minerals, especially calcium and phosphate, are the main contributors to the fouling of membranes. In addition, other recognized contaminants components at long time that are processing residues such as rennet, residual lipids, enzymes and microorganisms are prone to adsorb on the surface of the membrane, or promote gelation in the polarized layer or further induce the blocking of the pore, making the fouling even more complex.

Table 4 shows the physicochemical characterization of in nature whey and of concentrate and permeate fractions, as well as the rejection coefficient obtained with membrane of $10 \mathrm{kDa}$ at $10^{\circ} \mathrm{C}$ and 2 bar. Protein values obtained for membrane of $10 \mathrm{kDa}$ were shown to be higher for the concentrated fraction and lower for the permeate fraction when compared to the membrane of 50 and $100 \mathrm{kDa}$ under the same UF conditions. In terms of concentration percentage in relation to the in nature whey, the membrane of $10 \mathrm{kDa}$ presented concentration of approximately $44 \%$. This value was about 3 times higher than obtained for the membrane of $50 \mathrm{kDa}$, which had a concentration percentage of $16 \%$. The same behavior was observed for the solids content.

For the total minerals, conductivity and acidity, there was no significant difference $(\mathrm{P}<0.05)$ between in nature whey and concentrate and permeate fractions. Already for $\mathrm{pH}$, the permeate and concentrate fractions showed a slight increase, differing statistically from each other $(\mathrm{P}<0.05)$.

The membrane of $10 \mathrm{kDa}$ showed $80.48 \%$ of rejection for proteins, higher than obtained for the membrane of $50 \mathrm{kDa}(71.43 \%)$ under the same process conditions, where this behavior also was verified for solids and lactose. The higher retention rates for the membrane of $10 \mathrm{kDa}$ are attributed mainly to the smaller pore size, for lactose in specific, the retention observed is due to changes in the selectivity of the membrane caused due to the deposition of whey components that are deposited on the membrane, creating one additional resistance and hindering the permeation of lactose molecules.

To verify the main constituents that representing the proteins of concentrates and permeates obtained with the membrane of $10 \mathrm{kDa}$, an electrophoresis analysis was performed, and the figure 5 shows the

Table 4 - In nature whey constituents, concentrate and permeate fractions and rejection (\%) obtained by UF with membrane of $10 \mathrm{kDa}$ at $10^{\circ} \mathrm{C}$ and 2 bar.

\begin{tabular}{|c|c|c|c|c|}
\hline Constituents & In nature & Concentrate & Permeate & Rejection $(\%)$ \\
\hline Protein $\left(\mathrm{g} 100 \mathrm{~mL}^{-1}\right)$ & $0.82^{\mathrm{b}} \pm 0.03$ & $1.46^{\mathrm{a}} \pm 0.03$ & $0.16^{\mathrm{c}} \pm 0.02$ & 80.48 \\
\hline Solids (g $100 \mathrm{~mL}^{-1}$ ) & $5.81^{\mathrm{b}} \pm 0.03$ & $6.78^{\mathrm{a}} \pm 0.02$ & $4.15^{\mathrm{c}} \pm 0.09$ & 28.57 \\
\hline Lactose $\left(\mathrm{g} 100 \mathrm{~mL}^{-1}\right)$ & $4.96^{\mathrm{a}} \pm 0.01$ & $4.41^{\mathrm{b}} \pm 0.08$ & $4.16^{\mathrm{c}} \pm 0.0$ & 16.12 \\
\hline Minerals (g $100 \mathrm{~mL}^{-1}$ ) & $0.57^{\mathrm{a}} \pm 0.04$ & $0.48^{\mathrm{b}} \pm 0.03$ & $0.49^{\mathrm{b}} \pm 0.02$ & 14.04 \\
\hline Conductivity $\left(\mathrm{mS} \mathrm{cm}^{-1}\right)$ & $5.68^{\mathrm{a}} \pm 0.04$ & $5.61^{\mathrm{a}} \pm 0.06$ & $5.77^{\mathrm{a}} \pm 0.09$ & - \\
\hline Acidity $\left({ }^{\circ}\right.$ Dornic) & $12.67^{\mathrm{a}} \pm 0.57$ & $13.33^{\mathrm{a}} \pm 0.57$ & $13.00^{\mathrm{a}} \pm 0.50$ & - \\
\hline $\mathrm{pH}$ & $6.51^{\mathrm{c}} \pm 0.01$ & $6.55^{\mathrm{b}} \pm 0.01$ & $6.58^{\mathrm{a}} \pm 0.02$ & - \\
\hline
\end{tabular}

*mean ( \pm standard deviations) followed by same letters on lines represents no significant difference at 5\% level (Tukey's test). 


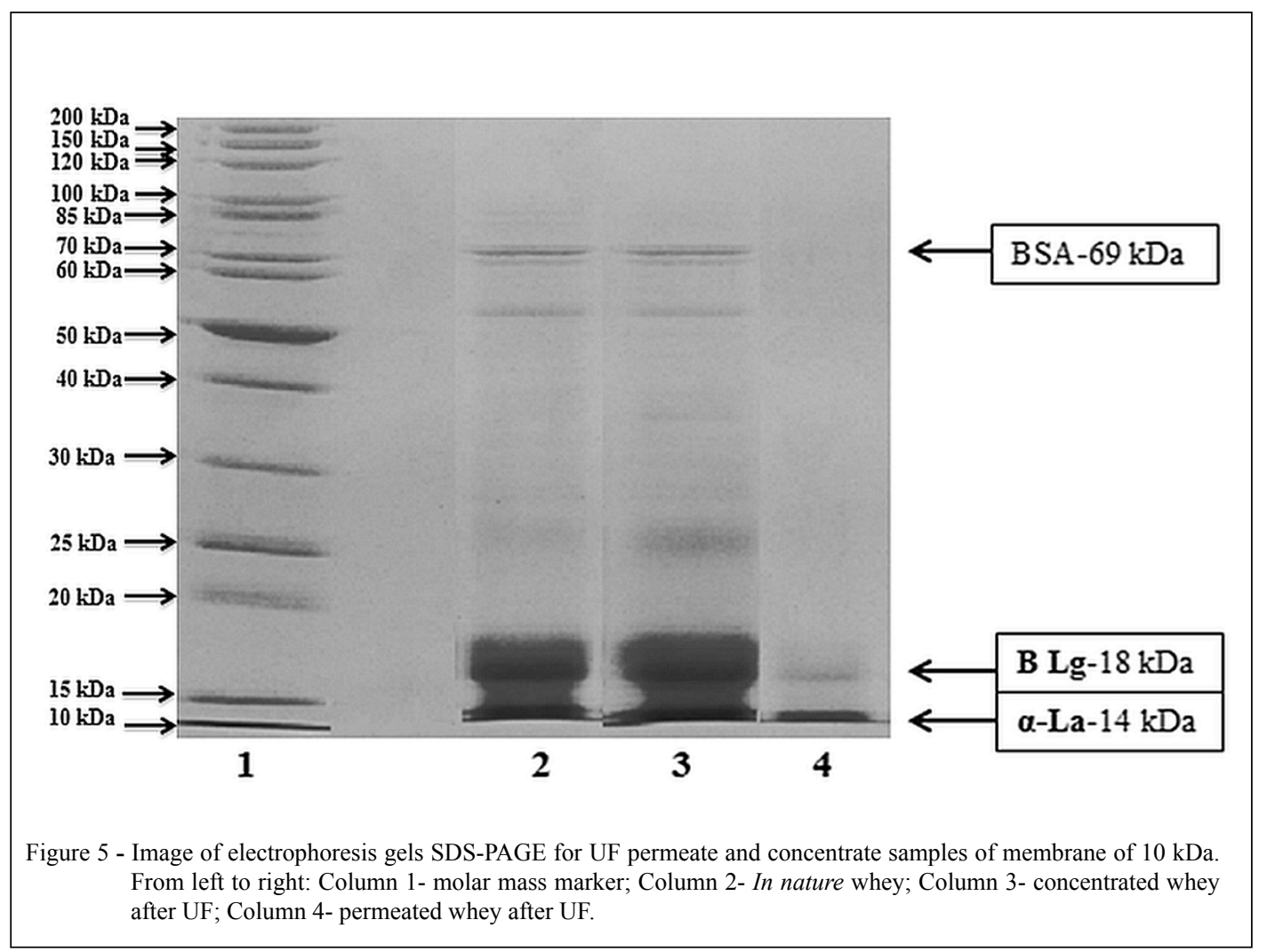

image of the electrophoresis gel. It is observed in the electrophoresis gel that the concentrate sample shows a weak signal for both proteins, $\beta$ - $\operatorname{Lg}$ ( $\beta$-lactoglobulin of $18.3 \mathrm{kDa})$ and $\alpha-\mathrm{La}(\alpha$-lactalbumin of $14.2 \mathrm{kDa})$, indicating that the two proteins are in the concentrate the membrane, since the membrane was $10 \mathrm{kDa}$, thus retaining proteins of molecular weight greater than $10 \mathrm{kDa}$. For the permeated fraction it is not noted a band BSA $(69 \mathrm{kDa})$.

Furthermore, the presence of other characteristic bands of minority proteins in the whey is verified, sub-fractions with different molecular weights, or even conformational variations of the proteins. These observations are in accordance with HARAGUCHI et al. (2006) which affirm that the fractions or whey peptides are composed of $\beta-\mathrm{Lg}, \alpha-\mathrm{La}$, BWA Immunoglobulins (Ig's) and glycomacropeptides (GMP), as well as sub-fractions or secondary peptides that may vary in size and molecular weight.

Table 5 presents the results of the analysis carried out on the samples of in nature whey and the fractions (concentrate and permeate) of membrane of 50 and $10 \mathrm{kDa}$. The constants $\mathrm{K}_{\mathrm{h}}$ and $\mathrm{K}_{\mathrm{s}}$ correspond to the size of the droplets generated, where $\mathrm{K}_{\mathrm{s}}$ is related to large droplets and $\mathrm{K}_{\mathrm{h}}$ with small droplets. As these

Table 5 - Values total protein, soluble protein, $\mathrm{K}_{\mathrm{h}}$ and $\mathrm{K}_{\mathrm{s}}$ for in nature whey, concentrate and permeate whey by membrane of 50 and $10 \mathrm{kDa}$.

\begin{tabular}{lcccc}
\hline Sample & Total protein $(\%)^{1}$ & Soluble protein $(\%)^{1}$ & $\mathrm{~K}_{\mathrm{h}}\left(\mathrm{min}^{-1}\right)$ & $\mathrm{K}_{\mathrm{s}}\left(\mathrm{min}^{-1}\right)$ \\
\hline In nature whey & $12.39^{\mathrm{b}}$ & $41.39^{\mathrm{b}}$ & $(6.7 \pm 2.0) \cdot 10^{-4} \mathrm{~b}$ & $(7.1 \pm 0.3) .10^{-3 \mathrm{a}}$ \\
Concentrate $50 \mathrm{kDa}$ & $12.69^{\mathrm{b}}$ & $57.82^{\mathrm{a}}$ & $(1.1 \pm 0.1) \cdot 10^{-3 \mathrm{a}}$ & $(5.8 \pm 0.6) \cdot 10^{-3 \mathrm{~b}}$ \\
Concentrate $10 \mathrm{kDa}$ & $22.66^{\mathrm{a}}$ & $54.40^{\mathrm{a}}$ & $(7.2 \pm 0.1) \cdot 10^{-8 \mathrm{c}}$ & $(1.2 \pm 0.2) \cdot 10^{-3 \mathrm{c}}$ \\
\hline
\end{tabular}

"means ( \pm standard deviations) followed by same letters on lines/columns represents no significant difference at $5 \%$ level (Tukey's test). ${ }^{1}$ Expressed in drv basis. 
constants represent the destabilization of the emulsion, the larger the droplets the more unstable the emulsion will be. The concentrated fraction of $10 \mathrm{kDa}$ showed lower $\mathrm{K}_{\mathrm{s}}$, than, has more stable emulsions. The small drops represented by $\mathrm{K}_{\mathrm{h}}$ are those that form cream more slowly with time, also corresponding to the concentrated fraction of $10 \mathrm{kDa}$. According to MCCLEMENTS (1999), the droplet size produced during the formation of the emulsions depends on two processes: the generation of small droplets and the rapid stabilization of these droplets, which avoids their coalescence.

In summary, the viability of the whey protein concentration process by membranes depends, largely, of the conditions as the membrane properties, flow type, membrane-solute affinity, solution temperature, pressure, among others.

\section{CONCLUSION}

Considering that the present study was carried out in a laboratory scale with conventional flow and flat membrane of 100,50 and $10 \mathrm{kDa}$, the viability of the process will depend on a scale up, preferably employing a tangential flow and ceramic membrane, which would reduce operating times, cleaning steps and polarization phenomena by concentration and fouling.

Recovery of whey constituents by UF is of great interest to the industry, being an alternative of adding value to the subproduct of the dairy industry. The concentrated obtained by UF in laboratory scale showed a mean protein retention of 55 to $80 \%$ for membrane of 100 and $10 \mathrm{kDa}$, respectively. Indicating the possibility of use in food industries with better emulsifying properties than the in nature whey.

\section{ACKNOWLEDGEMENTS}

The authors acknowledge for finnantial support: URIErechim, Coordenação de Aperfeiçoamento de Pessoal de Nível Superior (CAPES) and Conselho Nacional de Desenvolvimento Científico e Tecnológico (CNPq).

\section{DECLARATION OF CONFLICT OF INTEREST}

The authors declared no potential conflicts of interest with respect to the research, authorship, and/or publication of this article.

\section{REFERENCES}

ABISMAÏL, B. et al. Emulsification processes: on-line study by multiple light scattering measurements. Ultrasonics Sonochemistry. v.7, p.187-192, 2000. Available from: <http:// www.sciencedirect.com/science/article/pii/S1350417700000407> Accessed: Jun. 17, 2016. doi: 10.1016/S1350-4177(00)00040-7.
AOAC. Association Of Official Analytical Chemists. Official methods of analysis of the association analytical chemists. 18.ed. Maryland 2005.

ARUNKUMAR, A.; ETZEL, M.R. Negatively charged tangential flow ultrafiltration membranes for whey protein concentration. Journal of Membrane Science, v. 475, p. 340-348, 2015. Available from: $<$ http://www.sciencedirect.com/science/article/pii/ S0376738814008205>. Accessed: Jun. 20, 2015. doi: 10.1016/j. memsci.2014.10.049.

BALDASSO, C. et al. Whey fractionation through the membrane separation process. Separation Science and Technology, v. 5, p. 1862-1871, 2016. Available from: <http://www.tandfonline.com/ doi/abs/10.1080/01496395.2016.1188115?journalCode=lsst20>. Accessed: Jun. 18, 2015. doi: 10.1080/01496395.2016.1188115.

BARUKCIC, I. et al. Effect of pore size and process temperature on flux, microbial reduction and fouling mechanisms during sweet whey cross-flow microfiltration by ceramic membranes. International Dairy Journal. v.39, p.08-15, 2014. Available from: <http:// www.sciencedirect.com/science/article/pii/S0958694614000910>. Accessed: Jun. 15, 201.

BRANDELLI, A. et al. Whey as a source of peptides with remarkable biological activities. Food Research International. v.73, p. 149-161, 2015. Available from: <http://www.sciencedirect. com/science/article/pii/S0963996915000319>. Accessed: Jan. 20, 2016. doi: 10.1016/j.foodres.2015.01.016.

BRASIL - Instituto Adolfo Lutz - IAL. Physicochemical methods for food analysis. 4 ed. São Paulo 2005.

HARAGUCHI, F.K. et al. Whey proteins: composition. Nutritional properties. Sports applications and benefits to human health. Revista de Nutrição. v. 19, p.479-488, 2006. Available from: $\quad<$ http://www.scielo.br/scielo.php?script=sci arttext\&pid=S1415-52732006000400007>. Accessed: Jun. 15, 2016. doi: 10.1590/S1415-52732006000400007.

LAEMMLI, U.K. Cleavage of structural proteins during the assembly of the head of bacteriophage T4. Nature. v. 227, p.680685, 1970. Available from: $<$ https://www.nature.com/nature/ journal/v227/n5259/abs/227680a0.html>. Accessed: Jun. 10, 2016. doi: $10.1038 / 227680 \mathrm{a} 0$.

LOWRY, O.H. et al. Protein measurement with the Folin phenol reagent. Journal of Biological Chemistry. v.193, p. 265275, 1951. Available from: <https://www.ncbi.nlm.nih.gov/ pubmed/14907713>. Accessed: May. 10, 2016.

MACEDO, A. et al. Assessment of the performance of three ultrafiltration membranes for fractionation of ovine second cheese whey. International Dairy Journal. v.48, p. 31-37, 2015. Available from: $<$ http://www.sciencedirect.com/science/article/pii/ S0958694614002556>. Accessed: Jun. 19, 2016. doi: 10.1016/j. idairyj.2014.12.003.

MCCLEMENTS, D.J. Food Emulsions Principles. Practices, and Techniques. CRC Press. 1999.

MILLER, G.L. Use of dinitrosalucylic acid reagent for determination of reducing sugar. Analytical Chemistry. v.31, p.426-428, 1959. Available from: <http://pubs.acs.org/doi/ abs/10.1021/ac60147a030>. Accessed: Jun. 19, 2016. doi: 10.1016/j.idairyj.2014.12.003. 
PABBY, A.K. et al. Handbook of membrane separations: chemical, pharmaceutical, food, and biotechnological applications. 2.ed. New York: CRC PRESS, 2015.

PALATNIK, D. R. et al. Recovery of caprine whey protein and its application in a food protein formulation. LWT - Food Science and Technology. v. 63, p.331-338, 2015. Available from: <http:// www.sciencedirect.com/science/article/pii/S0023643815001802> Accessed: Jun. 19, 2016. Doi: 10.1016/j.lwt.2015.03.027.

PALAZOLO, G. et al. Coalescence and flocculation in o/w emulsions of native and denatured whey soy proteins in comparison with soy protein isolates. Food Hydrocolloids. v.19, p. 595-604, 2005. Available from: $<$ http://www.sciencedirect.com/science/article/pii/S0268005X04001766>. Accessed: Apr. 20, 2016. doi: 10.1016/j.foodhyd.2004.10.022.
PANIZZOLO, L.A. et al. Kinetics for Describing the Creaming of Protein-Stabilized O/W Emulsions by Multiple Light Scattering. Journal of Food Science and Engineering. v. 4, p. 236-243, 2014. Available from: <http://www.davidpublisher.org/index.php/ Home/Article/index?id=5556.html $>$. Accessed: Apr. 22, 2016. doi: 10.17265/2159-5828/2014.05.003.

SHAMES, I. H. Fluid Mechanics. 3 ed. Bogotá: McGraw-Hill. 1995.

WELSH, G. et al. Comparison of bioactive peptides prepared from sheep cheese whey using a food-grade bacterial and a fungal protease preparation. International Journal of Food Science and Technology. v. 52, p. 1252-1259, 2017. Available from: <http:// onlinelibrary.wiley.com/doi/10.1111/ijfs.13392/pdf $>$. Accessed: Apr. 22, 2017. doi: 10.17265/2159-5828/2014.05.003. 